\title{
A Bird's Eye View of Human Sex Determination
}

\section{P.E. Polani}

In the beginning the dogma was that sex determination in man followed the Drosophila pattern in which XO is male, XXY female, and the $\mathrm{Y}$ chromosome has no direct influence on the determination of sex. On the grounds of specific anomalies with which they presented, females with Turner Syndrome were sex chromatin tested and found to be chromatin negative [1]. This result, confirmed in 1956 by the male frequency of redgreen colour blindness in these subjects which indicated that they carried only one $\mathrm{X}$ chromosome in spite of their female phenotype, suggested that therefore they might be $\mathrm{XO}$, and, so, hinted that sex determination in man might not follow the then accepted pattern [2]. In 1959 chromosome studies confirmed that XOs were female [3] and showed that subjects with the symmetrical XXY sex-chromosome anomaly were with Klinefelter syndrome [4]. In the same year, by showing that XOs were females also in mice [5] it became accepted that the $\mathrm{Y}$ chromosome was the determiner of the formation of the testis in the mammalian embryo, and so was the key element in primary sexual differentation. It would seem appropriate to call this formal model of chromosomal sex determination the Malandrium pattern [6].

In 1966 Jacobs and Ross [7], from work on males with Y chromosome deletions narrowed down the testis determining function of the $\mathrm{Y}$ chromosome to its short arm. Then, in 1975, Wachtel and collaborators [8] were the first to formulate a hypothesis on the sex determining gene, or, more precisely on the nature of its product. They suggested that this developmental role might be played by the $\mathrm{H}-\mathrm{Y}$ antigen, a weak histocompatibility antigen which had been known to be involved in the rejection of male skin grafted onto otherwise histocompatible female mice. The idea had run into technical difficulties and a major problem was related to the significance that should be attached to the results of two different ways for demonstrating the antigen, namely the cell-mediated cytotoxicity test or the serological test. Efforts were made to keep the H-Y hypothesis alive, largely because there was a certain elegance about it $[9,10]$. However eventually XX male mice, lacking $\mathrm{H}-\mathrm{Y}$ by either test, spelt the end of the candidature of $\mathrm{H}-\mathrm{Y}$ as the testis determining mechanism $[11,12]$.

The next candidate for the maleness factor was the BKM DNA sequence identified as a satellite and apparently related to the heterogametic sex chrosomes across taxa, though perhaps BKM was not entirely sex-chromosome specific. The hypothesis that it was 


\section{P.E. Polani}

involved in sex determination had been advanced in 1981 by Jones and Singh [13] and was tested in mouse. However BKM was not a really convincing candidate for sex determination. Nevertheless it turned out to be useful because it helped to unravel the mystery of Cattanach's sex reversed mutation in the mouse; and, in humans, it supplied support for the idea that in most $\mathrm{XX}$ males there was transfer of material from the $\mathrm{Y}$ to one of the chromosomes [14, 15] Ferguson Smith in 1966 had suggested that XX males and true hermaphrodites might arise from an intercharge between the $\mathrm{X}$ and $\mathrm{Y}$ chromosomes [16; see also 17].

By 1980 Solari [18], by electron microscopy of microspreads of meiotic cells at pachynema, resolved an important issue that concerned the manner of pairing of the human $\mathrm{X}$ and $\mathrm{Y}$ chromosomes at meiosis; an issue which had been thought unresolvable cytologically. His observations defined a zone of terminal pairing between the short arms of the $\mathrm{X}$ and $\mathrm{Y}$ chromosomes and defined its extent. The zone of crossing over within it could be worked out, as well as the constrained variability of the positions of the apparently single crossing over event [19]. From Solari's observations it was possible to estimate the sizes of the telomeric pairing and normal crossing over segments of the $X$ and $\mathrm{Y}$ chromosomes and to put some tentative figures on the probabilities that the maleness factor be involved in unusual crossing over exchanges between the $\mathrm{X}$ and the $\mathrm{Y}$ chromosomes, and so on the production of XX males and of some $\mathrm{XY}$ females with Pure Gonadal Dysgenesis (for this see [21]]. It was also possible to make an estimate of the size of the problem that would be faced if one explored this region of the $Y$ chromosome at the DNA level [19]. In parallel the $X$ and $Y$ paring and crossing over situation was examined by Burgoyne [19] who defined the normal crossing over recombination zone between the $\mathrm{X}$ and $\mathrm{Y}$ chromosomes as "pseudoautosomal", in view of the behaviour that could be expected from gene loci there [20].

In terms of classical human genetics the observations on the paring of $\mathrm{X}$ and $\mathrm{Y}$ chromosomes with crossing over exchange resolved the long standing issue concerning the existence and demonstrability of partial, or incomplete, sex linkage $[22,23,24]$ and the cytological evidence against it [25]. Now Goodfellow's observations (264) on MIC2, an antigen-encoding gene, have defined the first pseudoautosomal human gene in the standard crossing over region and he has pinpointed its location. Furthermore he has made observations about a more proximal locus, $\mathrm{Yg}$, related to the $\mathrm{Xg}$ locus and has suggested that it may be concerned with the control of the latter's expression. The behaviour of $\mathrm{Xg}$ on the short arm of the $\mathrm{X}$ chromosome in relation to its occasional crossing over, and the existence of an $\mathrm{Xg}$-related locus on the $\mathrm{Y}$ chromosomes had been previously considered [19].

In 1987 the investigation (discussed in 27) of the male-determining region of the $Y$ chromosome by recombinat DNA methods led to the costruction of a molecular map of the Y chromosome's short arm, by exploiting information derived from XX males and $\mathrm{XY}$ females with so-called Pure Gonadal Dysgenesis. As a result it became possible to assign the testis-determining locus to the more distal part of the short arm of the Y chromosome, proximal to the pseudoautosomal region, and to define DNA probes within a few million base pairs of the locus. The next step was taken by Page and his collaborator [28] who constructed a deletion map of the relevant part of the short arm of the Y chromosome. By using information from an XX male and an XY female, they concluded that a defined interval, named $1 \mathrm{~A} 2$, contained most if not all of the testis determining factor, 
TDF. These workers identified a DNA sequence from which they derived the make up of a protein which had the characteristic of a zink finger protein; and they named the gene coding for it ZFY (a homologue on the X chromosome they named ZFX). They considered that ZFY probably was the sex determining gene on the Y chromosome [29]. However there were some difficulties. Some XX males did not display ZFY. Furthermore a subset of these ZFY-negative males, though they did not carry ZFY, nevertheless carried material from the $Y$ chromosome's relevant region [30; see also 31). The answer had to be that ZFY could not possibly be the testis-determiner, which instead ought to be sought now in the smaller DNA segment, about $60 \mathrm{~kb}$, detected by these workers [32]. The size of this segment was further narrowed down to $35 \mathrm{~kb}$, and a search of this region identified a new gene which, I quote: "is conserved and Y-specific among a wide range of mammals, and encodes a testis specific transcript. It shares homology with the matingtype protein, Mc, from the fission yeast Saccharomyces pombe and a conserved DNAbiding motif present in the nuclear high-mobility-group proteins HMG1 and HMG2. This gene has keen termed SRY (for sex-determining region $\mathrm{Y}$ ) and proposed to be a candidate for the elusive testis-determining gene, TDF" [31]. Further genetic evidence in support of this statement was provided by XY women who did not have a deletion of SRY but in whose gene, instead, a mutation was identified, confirming that SRY is the testis determiner [33]. A homologous gene [34] was detected in the mouse and termed Sry. When this gene was inserted into a series of mouse embryos, a few of the resulting transgenic females were shown to carry testes [35], evidence for the testis-determining role of the inserted DNA. This was reinforced by observations on the time and place in embryonic life when Sry is expressed, as well as the independence of its expression from the presence of germ cells [36].

The evolutionarily conserved part of SRY codes for the HMG box of 79 amino acids, while the total human SRY protein has 204 aminoacids, 58 of which are at the aminoterminal end from the box [37]. Tentative sussestions about the mode of action of SRY come from its relation to the HMG high-mobility-group proteins which can intercalate into the lesser groove of DNA, induce bending, and so may affect transcription. The protein has also an affinity for Holliday-like junctions [37]. AS for the way the testis determiner would act at embryo level, it is suggested that it may influence undifferentiated progenitor cells in such a way that their differentiation be canalized to form Sertoli's sustentacular cells [37]. It is considered that this is the key event that heralds in testis differentiation from the indifferent gonadal anlage [38]. The timing of the onset of differentiation appears to be critical, and is correlated with, if not related to, the generally advanced growth rate of the fetus [39].

The question is being asked whether SRY, is the "master" gene in human, and homologously in eutherian sex determination. The short answer seems to be that its presence is necessary, but not a sufficient condition. If it is absent, deleted in part or mutated, testis development does not procced, it can be said with assurance that it holds the key to testis development. However, in humans there appears to exist, judging from the XY sex reversed camptomelic dwarfism, an autosomal gene which, when mutated, seems to be able to prevent testis formation in spite of an apparently normal male sex chromosomes complement [40]. There are also examples of XY females with Gonadal Dysgenesis (or agonadal), who seem to have normal SRYs, and would support the contention that the action of the gene can be overridden, or regulated(?) [37]. 


\section{P.E. Polani}

In mice there appears to exist a situation similar to that in man, with Sry being overridden by an autosomal gene, or genes, in XY offspring from certain racial crosses [41]. Possibly another example comes from the wood lemming in which a discrete structural change of the $\mathrm{X}$ chromosome results in a female phenotype in spite of a normal $\mathrm{Y}$ chromosome [42].

\section{REFERENCES}

1. Polani PE, Hunter WF et al. (1954): The Lancet II: 120-121.

2. Polani PE, Lessof MH. et al. (1956): The Lancet I: 118-120.

3. Ford CE, Jones KW et al. (1959): The Lancet I: 711-713.

4. Jacobs PA, Strong JA (1959): Nature 183: 302-303.

5. Welshons WJ, Russel LB (1959): Proc Nat Acad Sci USA, 45: 560-566.

6. Westergaard M (1958): Advanc Genet 9: 217-247.

7. Jacobs PA, Ross A (1966): Nature 210: 352-236.

8. Wachtel SS, Ohno S (1975): Nature 210: 352-354.

9. Polani PE, Adinolfi M (1983): J Immunogenet 10: 85-102.

10. Polani PE, (1985): In J Ghesquire, RD Martin Eds Human sexual dimorphism Taylor \& Francis, London 443-445.

11. McLaren A, Simpson E et al. (1984). Nature 312: 552-555.

12. Goldberg EH, Mclaren A et al. (1984): J Reprod Immunol.

13. Jones KW, Singh L (1981): Hum Genet 58: 46-53.

14. Singh L, Jones K.W. (1982): Cell (Cambridge, Mass), 28: 205-216.

15. Evans EP, Burtenshaw MD, et al. (1982): Nature, 300.

16. Ferguson Smith, MA (1966): Lancet, II, 475-476.

17. Evans HJ, Buckton KE (1979): Hum Genet 49: 11-31.

18. Solari AJ (1980): Chromosoma 81: 315-337.

19. Polani PE (1982): Hum Genet 60: 207-211.

20. Burgoyne PS (1982): Hum Genet: 61: 85-90.

21. Polani PE (1981): In CR Austin, RG Edwards, Eds Mechanisms of Sex Differentiation in Animals and Man 465-547 Academic Press, New York.

22. Haldane JBS (1936): Ann Eugen 7: 28-57.

23. Fisher RA (1936): Ann Eugen 7: 87-104.

24. Maklin MT (1952): Amer J Hum Genet 4: 14-30.

25. Sachs L (1954): Ann Eugen 255-261.

26. Goodfellow PN (1987): Development (Cambridge), Suppl 101: 119-125.

27. Muller U (1987): Development (Cambridge), Suppl 101: 51-58.

28. Page DC, Mosher R et al. (1987): Cell (Cambridge, Mass) 51: 1091-1104.

29. Page DC (1988): Phil Trans R Soc London, B, 322: 155-157.

30. Palmer MS, Sinclair AH (1989): Nature 346: 240-244.

31. Sinclair AH, Berta P, et al. (1990): Nature 346: 240-244.

32. Goodfellow PN, Hawkins JR et al. (1991): In Davies, SM Tilghman Eds Genome Analysis, 3, Cold Spring Harbor Lab Press. 
33. Berta P, Hawkins JR et al. (1990): Nature 348: 448-450.

34. Gubbay J, Collignon J et al. (1990): Nature 346: 245-250.

35. Koopman P, Gubbay J et al. (1991): Nature 351: 117-121.

36. Koopman P, Munstreberg A et al. (1990): Nature 348: 450-452.

37. Goodfellow PN, Lovell Badge R (1993): Ann Rev Genet 27: 71-92.

38. Jost A, Magre S (1988): Phil Trans R Soc Lond B 322: 55-61.

39. Mittwoch U (1992): Hum Genet 89: 467-479.

40. Tommerup N, Schempp W et al. (1993): Nature Genetics 4: 170-174.

41. Eicher EM (1988): Phil Trans R Soc Lond B322: 109-118.

42. Fredga K, Gropp A et al. (1976): Nature 261: 255-257.

Correspondence: Prof. P.E. Polani, MD FRS, Little Meadow, West Clandon, Surrey GU4 7TL, United Kingdom. 